\title{
The Politics of Linking Educational Research, Policy, and Practice: The Case of Improving Educational Quality in Ghana, Guatemala and Mali $^{1}$
}

\author{
MARK GINSBURG, DON ADAMS, THOMAS CLAYTON, MARTHA \\ MANTILLA, JUDY SYLVESTER and YIDAN WANG*
}

\begin{abstract}
This paper examines the political dimension of the educational research undertaken by Ghanian, Guatemalan, and Malian teams as part of the 1991 to 1996, USAID-funded "Improving Educational Quality" (IEQ) project. The following questions are addressed: (a) why were (or were not) aspects of the educational reforms studied by the researchers; (b) why were (or were not) research findings used in decision-making about the educational policies and practices associated with the reforms; and (c) why were particular institutional arrangements and funding levels constituted for the research and dialogue activity. In offering answers to these questions, attention is paid to local, national, and global power relations and resource distributions.
\end{abstract}

\section{Introduction}

D URING THE LATTER two decades of the twentieth century the global economy has been radically reorganized through actions of multinational corporations, multilateral organizations (e.g., the World Bank and the International Monetary Fund), and national governments, particularly the United States (see Braun 1997). Paralleling the dissolution of the Soviet Union and the bloc of "socialist societies" in Central/Eastern Europe has been the emergence of "disorganized capitalism" - "the geographical dispersal of production and distribution through the

* Institute for International Studies in Education, University of Pittsburgh, Pittsburgh, PA, 15760, U.S.A. 
globalization of markets and industrial deconcentration" (Gilbert 1997:66). These dynamics provide major political economic challenges for those seeking to steer nation-states.

Given that during periods of political economic crisis or transformation, whether at the national or global level, the volume of educational reform rhetoric and action tends to increase (Ginsburg 1991), we should not be surprised that the 1980s and 1990s witnessed widespread international concern for improving educational quality (Chapman and Carrier 1990; Hallak 1990; Ross and Mahlck 1990). This focus on reforming education has deflected attention from political economic dynamics, making education the problem and the solution. At the same time concerns about education have been shifting from issues such as expanding access and retention to improving the quality inputs, processes, and outputs of education for all children (e.g., Inter-Agency Commission 1990).

This is the context in which the Improving Educational Quality (IEQ) project was conceived and implemented. Initiated in 1991 as a five-year, United States Agency for International Development (USAID)-funded project, IEQ's main objective was stated as designing practical ways to improve learning in classrooms and schools within the context of national educational reforms in selected developing countries. In the three countries supported under the core contract - Ghana, Guatemala, and Mali ${ }^{2}$ - IEQ formed partnerships with one or more host-country institutions to:

- assist in the enhancement of country research capacity and application;

- collaboratively design and implement classroom research at the primary school level; and

- link findings to practice and policy at various levels (from classrooms to national ministries) of the educational systems.

Research teams composed of local researchers (and, over time, administrators, supervisors, and teachers) developed their capacity as disciplined inquirers and conducted investigations - collecting, analyzing, and interpreting data in the context of classroom-anchored research (Ginsburg et al. 1996). IEQ studies examined how children of different characteristics (e.g., ethnicity, gender, language proficiency) interacted with ongoing or modified school practice and what consequences this had for various kinds of development and achievement. Moreover, based on the assumption that conducting such research is a necessary but insufficient condition for identifying, developing, and sustaining changes that improve educational quality, IEQ also stressed feedback to, and dialogue with, teachers, head teachers, districtlevel supervisors, parents, ministry of education and other government officials, as well as representatives from bilateral and multilateral donor agencies.

During the documentation research effort, ${ }^{3}$ the authors developed the notion of Policy-Practice-Research-Dialogue (PPRD) cycles which we employed as a heuristic device in analyzing the activity undertaken within the three centrally- 
funded or "core" countries of the IEQ Project (see Ginsburg and Adams 1996). The PPRD cycles concept orients us to the possibility of various combinations of linkages between these components. For instance, we can investigate how research findings are (or are not) drawn upon in decisions about initiatives to improve educational quality. The PPRD cycles concept also orients us to investigate the role of people and institutions exogenous as well as endogenous to each of the countries. Thus, in addition to focusing on teachers, school administrators, parents, and government ministries in Ghana, Guatemala, and Mali, we examine the activity of USAID and other international organizations and bilateral aid agencies in relation to each country. Also, besides highlighting the work of Ghanaian, Guatemalan, and Malian members of the respective Host Country Research Teams, we pay attention to the activities of U.S. consultants who are designated as members of the U.S. Research Support Teams.

In this paper we employ the PPRD cycles model to examine the political dimension - pertaining to the distribution of power as well as material and symbolic resources (see Ginsburg 1995; Ginsburg and Lindsay 1995) — of the relationships among educational policy, practice, and research undertaken within local, national, and global political, economic, and educational system contexts. Knowledge and power are inextricably linked (Foucault 1980), but "the relations between power and knowledge [are sometimes] made invisible" (Popkewitz 1991:225). Thus, the process of searching for and claiming the legitimacy of knowledge - in other words, research - is both constituted by and constitutive of power relations. As Pan (1990:12) observes, research is political in the determination of "the directions and topics of research" and the interpretation of "the results of research." This is especially the case when research is explicitly undertaken to inform policy and practice, for example, in the field of education. Whether one approaches such activity within a framework of "decision-oriented research" (Cooley and Bickel 1986), "collaborative action research" (McTaggert 1991; Stenhouse 1975), or "research as praxis" (Bodemann 1978; Lather 1991), efforts to link research to policy and practice clearly have a political dimension. Not only is such research imbedded in knowledge/power relations, but it is also connected to the distribution of material and symbolic resources to different groups of policy makers, educators, students, and other worker-consumer-citizens (see Ginsburg 2000).

\section{Case Studies of Policy-Practice-Research-Dialogue Cycles}

Below we provide an overview of the societal contexts and present brief descriptions of decision-making and other activities that occurred in the three IEQ core countries relevant to understanding the links between policy, practice, research, and dialogue. 


\section{Social Context and PPRD Cycles in Ghana}

Ghana, a West African country with a population of about 17 million, gained its political independence from Britain on 6 March 1957. It is an ethno-linguistically diverse society, containing at least 44 indigenous languages which belong to one of 13 major language groups, although English is the official language and the sole medium of instruction (beginning with the fourth year of primary school). Economically, Ghana could be characterized as a dependent, though richly resourced, producer of cocoa, gold, diamonds, and timber (Agbodeka 1992). After years of expansion and despite government action, the Ghanaian economy experienced a severe decline stemming from the global oil crisis of 1973 to 1974 as well as drought-induced low crop yields in 1975 to 1976 and 1981 to 1983. With external debt having risen tenfold between 1974 and 1981, the Ghanain government launched in April 1983 its Economic Recovery Program (ERP), and negotiated loans from the IMF and World Bank, based on the promise to adopt a Structural Adjustment Program, including the reduction in public expenditures on education and other social services (Rothchild 1991).

In this political economic context, successive governments in Ghana have articulated commitments to educational development. Up until the mid-1970s Ghana had one of the most advanced educational systems in West Africa, with an estimated enrollment rate of 75 percent of children aged 6 to 14 years. However, during the subsequent economic downturn, investment in education also dropped drastically, plunging the system into a crisis. For example, the availability of basic textbooks ranged from nil to inadequate. Moreover, teachers' salaries plummeted and thousands of teachers deserted the classrooms (Yeboah 1992), making it necessary to deploy an "emergency," less-than-optimally trained teaching force. By 1990, the literacy level of the population had declined to 60 percent. Despite government policy commitments and international funding for national reform initiatives, such as the Primary Education Program (PREP) initiated in 1991, educational resources remain limited and inequitably distributed across regions, ethno-linguistic groups, and gender (Wolf 1995:11).

In April 1992, when representatives of USAID/Accra, the Government of Ghana and the Institute for International Research (IIR), the prime contractor for the IEQ project, met to discuss where to focus IEQ resources, PREP was the clear choice. The major activities of USAID-funded PREP included: (a) distributing instructional materials; (b) developing criterion-based tests for primary school leavers in grade 6; (c) organizing a comprehensive inservice education program for primary school teachers; and (d) preparing and implementing an Equity Improvement Plan in the Central Region. It was decided that IEQ's classroombased research in the first (or pilot) phase of the project should focus on the 
availability and use of instructional materials in primary level (P1-P6) English, math and science classes.

By October 1992 the Ghanaian Host Country Research Team (HCRT) had been created. The HCRT was staffed by members of the Faculty of Education at the University of Cape Coast (UCC), which at this time established the Centre for Research in Improving Quality of Primary Education in Ghana (CRIQPEG). To launch the IEQ Project in Ghana, in October 1992, UCC hosted the First National Conference on Improving the Educational Quality of Primary Schools in Ghana. This conference was attended by representatives of the Ministry of Education, Ghana Education Service, the Overseas Development Association, UNICEF, USAID/Accra, local administrators, teachers, and parents of school children. Others in Ghana learned about the conference's content through national television and newspaper coverage.

During Phase I (October 1992 to March 1993) CRIQPEG's research team collected data from eighteen P1 to P6 classrooms in 6 primary schools in the Central Region through classroom and pupil observations and interviews with teachers, pupils, parents, and community and school leaders. The results from CRIQPEG's pilot study, reported in June 1993, suggested that many Ghanaian pupils had few opportunities in (or out of) school to acquire even basic English language skills. For example, textbooks were often not available, and when available, the texts were generally not being used by pupils - a state of affairs which was known or assumed to be the case by Ministry officials. However, the researchers also provided new insights when they reported that: (a) textbook availability was limited because head teachers did not have funds to travel to district distribution centers to obtain the PREP-sponsored books for their schools and (b) teachers did not distribute the texts to pupils, even when they were available in the school, because they wanted to avoid paying for any damage the books might suffer in the hands of pupils.

The results of IEQ's Phase I study were widely discussed with various groups at different levels of the system, including during the Second National Conference on Improving the Educational Quality of Primary Schools in Ghana, hosted by CRIQPEG at UCC on 6 October 1993, and attended by representatives from USAID, the Ministry of Education, the World Bank, the Overseas Development Association, UCC, as well as local head teachers, teachers, and parents.

The discussion stimulated by the Phase I findings eventuated in two changes in national-level policy, although not until 1995 - approximately one and onehalf years later and after the Phase II research had confirmed the Phase I findings. First, a new policy was adopted authorizing payment to head teachers' for the cost of traveling to district offices to collect textbooks for their schools. Second, the policy, which held teachers fiscally responsible for textbooks soiled or damaged by student use in class or at home, was rescinded. 
The research design for Phase II was planned over the summer and fall of 1993 during discussions among the CRIQPEG researchers, with input from the Project Director and other U.S. technical consultants. A USAID/Ghana official also had a major influence. The following recommendations proposed by this official were adopted:

- expand the sample of schools to 14 schools (7 experimental and 7 control schools) and include schools from the Western Region as well as the Central Region;

- focus on identifying "new instructional strategies which might be used nationwide"; and

- limit the study to the investigation of teaching and learning of English (and not on math and science) in the upper primary grades (only).

The latter recommendation was motivated by the poor performance of students on (a) the Spring 1993, USAID/PREP-administered, criterion-referenced tests of English literacy administered to a sample of P6 pupils as well as (b) the Ministryadministered Senior Secondary School Examination, reported in the Fall of 1993.

To establish a picture of pupil proficiency, CRIQPEG, working with IIR consultants, developed a curriculum-based assessment approach, developing tests that directly reflected the curricular content that was to be taught at specific grade levels. Starting in January 1994, CRIQPEG researchers used their curriculumbased assessment tools to measure the language ability of 1,032 pupils from 56 classrooms, in grades P2 to P5, in the expanded sample of 14 schools. During March to April 1994 they also conducted classroom observations and interviewed pupils, parents, teachers, head teachers, and circuit supervisors in the 14 participating schools. The findings from this first stage of the Phase II research, which (as noted above) confirmed the major Phase I research findings, were presented to and discussed with various groups at different levels of the system.

At the same time the CRIQPEG researchers were gearing up for the second stage of Phase II classroom observations and interviews which focused on (a) specifying the most serious teaching-learning problems and (b) determining possible interventions, e.g., instructional, testing, and classroom management strategies. Analysis of the second stage of Phase II data compared teachers and their students in grades P2 to P5 in the intervention schools with their counterparts in the nonintervention (or control) schools. The findings showed that, after receiving training and coaching from CRIQPEG, the teachers in the intervention schools (compared to the control school sample) exposed their pupils more to oral and written English (via textbooks and other instructional resources, posters and visual aids). The pupils in the intervention schools also evidenced higher levels of oral and written communication skills. 
These findings and other issues, including the key role that head teachers and circuit supervisors played in guiding teachers in developing their pedagogical strategies, were part of the "dialogue" at the CRIQPEG-organized and hosted Third National Conference on Improving the Quality of Primary Schools in Ghana held on 25 October 1994. Approximately 50 educators attended, including circuit supervisors and head teachers from the 7 intervention schools as well as representatives from the Ministry of Education and the Ghana Education Service, donor agencies, a local teacher training college, the UCC and school-level parentteacher organizations.

Following initial discussion about the Phase III research which occurred in Ghana at a CRIQPEG-organized "feedback seminar" in August 1994, two U.S. consultants drafted the research design for Phase III at a September 1994 working session at IIR in Washington, D. C. Their proposal included one critical design change: to study P3 to P6 classes rather than continuing to focus on P2 to P5 classes. The proposed change, which was strongly supported by USAID Mission in Ghana, was eventually accepted by CRIQPEG, although team members were initially more interested in studying the early primary years.

In November 1994 training teams - composed of CRIQPEG researchers, head teachers, and circuit supervisors - conducted workshops for teachers in the 7 intervention schools on the previously-proposed and newly-identified instructional and classroom management strategies. Over the next months head teachers and circuit supervisors assisted intervention-school teachers in implementing the strategies, as well as collected data (in May and July 1995) through observing and interviewing teachers and (P3-P6) students, administering CBA tests, and interviewing parents at all 14 (intervention and control) schools.

The findings evinced continued changes in teachers' classroom activity (less reliance on the chalkboard, more use of textbooks and other print materials, more reinforcement of pupils' use of English in class, and encouragement of pupils' use of English outside of class), as well as significantly greater improvement in pupils' reading, writing, listening, and speaking skills in the intervention schools. Findings from the initial data collected during the Phase III research were discussed with various stakeholders, even as data collection and analysis continued. For example, such discussions - and their implications for improving educational quality - occupied much of the agenda at the long-delayed, inaugural meeting of the IEQ National Advisory Board held in April 1995. This and subsequent meetings of the Board (in October and December 1995, and in March, June, and September 1996) were attended by Ministry of Education and Ghana Education Service officials, PREP administrators, and teacher union representatives, as well as circuit supervisors, head teachers, teachers and parents. Partly as a result of such discussions of the findings from both stages of Phase III research, the Ghanaian 
government decided to adopt on a nationwide basis the CBA instruments which had been developed in the IEQ project.

\section{Context and PPRD Cycles in Guatemala}

Guatemala, a Spanish colony until 1821, is the third largest and most populous Central American country (with over 9.5 million inhabitants). Guatemala's population is 70 percent rural and approximately 60 percent Indian, who speak 22 Mayan languages (Jones 1991); the rest of the population are ladinos, Spanishspeaking descendants of white and Indian racial intermixing. Guatemala's dependent economic status as a nation is coupled with extreme poverty and malnutrition; 72 percent of the population in 1990 was unable to afford a minimal diet, with the rates being higher for rural dwellers and Indians (Jones 1991). The abject poverty juxtaposed with concentrations of wealth has led to long-term social and political unrest, including a 30-year long (1960s to 1990s) civil war from which Guatemala only emerged in 1996.

In this political economic context it is not surprising that Guatemala has one of the lowest literacy rates in Central America, according to a 1987 UNICEF report (Hayes 1993). In 1993 Guatemala's literacy rate was 58.9 percent, meaning that there were 2.3 million illiterates, which constituted 41 percent of the population 15 years old or older (Pinto Paiz 1994). School enrollment rates are low overall, with rural, Indian, Mayan-language speaking, and female children being the least likely to attend, let alone complete, primary school. Even for those children who are enrolled in the school, attendance is irregular and dropout and repetition rates are high. In the face of these educational (and political economic) challenges, the Guatemalan government (in cooperation with various international organizations and bilateral aid agencies, notably USAID) has developed several reform efforts. One of these was the Basic Education Strengthening (BEST) program, a seven-year (1989 to 1996) project undertaken by the Ministry of Education and supported by a grant from USAID.

From February to October 1992, various discussions took place, at times involving representatives from two or more of the following organizations: the Guatemalan Ministry of Education, USAID/Guatemala, USAID/Washington, the Universidad Rafael Landivar, the Universidad del Valle, various donor organizations, and the Institute for International Research (IIR) and Juarez and Associates (both representing the IEQ project). While several reform initiatives (some funded by USAID and some not) were considered, participants agreed to follow the recommendation of the Minister of Education that IEQ focus on the Nueva Escuela Unitaria (NEU or New Unitary School) component of the BEST program, which was then at the midterm of implementation. The NEU model was based on an approach developed in Colombia; after visiting there, the Guatemalan Minister of Education 
had enthusiastically promoted implementing this program for her country. IEQ's research would compare schools employing the NEU model — involving flexible promotion; active, collaborative learning; peer teaching; use of self-instructional guides; and participatory student government - with traditional or Escuela Unitaria (EU) schools.

A Host Country Research Team (HCRT) was assembled, including a research coordinator, two regional field coordinators, and ten field researchers. Originally, it was thought that the HCRT would become part of an Institute for Educational Research within the Ministry of Education, plans for which were being discussed at the time when negotiations about IEQ in Guatemala were taking place. However, with a change of education ministers after an aborted coup by the then President of Guatemala in 1993, the plan for creating an Institute for Educational Research was discarded. Instead, in February 1996 (the final year of the IEQ project), the HCRT formally became part of the Institute of Educational Research at the Universidad del Valle. Moreover, it took until September 1995 to convene a National Advisory Committee for the IEQ Project in Guatemala. This was due to a number of factors, including an attempted vote of no confidence in early 1995 against the Minister of Education who had been appointed after the aborted coup in 1993.

Designed as a longitudinal evaluation study of the NEU component of BEST, 4 the IEQ research began in Phase I with the collection of data in ten (5 NEU and 5 EU) schools in each of two regions (II and IV). In-depth classroom observations, (cognitive and socio-emotional development, health status, and language proficiency) testing, and interviews were conducted in February and September/October 1993. The findings showed that both malnourished and well-nourished children in the NEU schools, especially those where the NEU model had been well implemented, evidenced significantly greater gains during the year than their counterparts in the traditional (EU) schools on several test measures, including reading comprehension in Spanish.

Dialogue ${ }^{5}$ began even before the post-test data were completely collected. For example, in October 1993 the HCRT Research Coordinator participated in NEU seminars for teachers, parents, and pupils in the two regions to discuss the findings from pre-test data and to review vignettes (transcribed from videos recordings) of classroom interaction in NEU and EU schools. And in August and September 1994 - just prior to the start of Phase II data collection, IEQ personnel and NEU developers organized workshops for all teachers, (regional and department) administrators, and supervisors connected with the NEU schools, as well as Ministry of Education officials and USAID/Guatemala representatives.

Phase II data collection, focusing on second- and third-grade classrooms during September to October 1994, entailed a longitudinal extension of that which was undertaken in Phase I. Findings indicated no significant differences between children in the NEU and EU schools in terms of gains in vocabulary and reading 
comprehension, comparing scores at the end of Phase I with those at the end of Phase II. And although there was some evidence of greater use of small group work and active learning opportunities for pupils in the NEU classrooms, in both groups of schools pedagogies involving repetition, drills, copying, and reading aloud were found to dominate, indicating no substantial training effect.

Dialogue activities included a three-day workshop (13 to 15 February 1995) for seven Ministry of Education personnel and two UNICEF staff. Although this workshop was designed primarily to provide training in research methodology, the use of IEQ findings and vignettes (transcribed from video recordings) of classroom interaction meant that discussions also focused on the NEU-EU comparisons and other aspects of the IEQ project's evaluation of BEST. Additionally, on 30 May and 2 June 1995, the HCRT coordinator conducted workshops for teachers working in NEU schools in Region II and Region IV, respectively. And in September 1995 a meeting was held of the National Advisory Committee created by IEQ with participants from the Ministry of Education, the Universidad de Valle, Rafael Landivar University, USAID/Guatemala, and UNICEF. At this meeting discussions focused, among other things, on the interpreting the contrasting results from Phase I and Phase II IEQ research.

In Phase III the longitudinal study continued, with data being collected on third and fourth grade classrooms during June to July 1995. Initial findings from the analysis of Phase III data indicated that the structure of classroom organization differed between NEU and EU schools, with the former being characterized as less teacher-centered and having more variety of instructional activities than the latter.

Discussion about IEQ research occurred at the 15 to 17 April 1996 workshops, which were organized for department and regional administrators, supervisors, teacher trainers, and teachers from Regions II and IV. IEQ research was also drawn upon during the "Latin American Conference on Educational Quality," which was co-sponsored by IEQ and the Universidad del Valle during 23 to 25 April 1996. In attendance were the Vice Minister of Technical Affairs - representing the new Minister of Education, who had been appointed in January following the election of a new President of Guatemala; national, regional, and department level officials of the Ministry of Education; representatives from Guatemalan research organizations and universities; educators and researchers working in educational reform in Brazil, Colombia, the Dominican Republic, Ecuador, Honduras, Nicaragua, and Puerto Rico; and representatives of USAID, UNICEF, and the World Bank.

\section{Context and PPRD Cycles in Mali}

Mali, which gained its political independence from France in 1960, is one of the largest countries in West Africa. Mali's population of approximately 8.5 million is about 80 percent rural and consists of 15 major ethnic groups (Ouane 1994) who 
speak 11 different languages (World Bank 1988). Only about 10 percent of the population speak French, the official language (Bokamba 1991). Mali's economic situation is one of dependency with extensive poverty, particularly in the rural areas (Ouane 1994).

School enrollment rates in Mali are very low, and there is significant repetition and dropout (UNESCO 1991). This situation exists despite various educational development efforts. For instance, in 1989 the Malian government launched its Basic Education Expansion Program (BEEP), a major national reform of primary schooling supported financially by USAID and the World Bank. BEEP also has a research component, and its findings about the low literacy and numeracy levels of Malian students were cited by the USAID/Mali Mission in requesting inclusion as a core country in the IEQ Project.

Discussions about IEQ in Mali began in July $1992^{6}$ and involved representatives of the Ministry of Education, USAID/Mali, and IIR. By April 1993, when formal "cooperative agreements" were signed, it had been decided to create a Host Country Research Team (HCRT) composed of eight members, four members each from the following two education ministry units, which from October 1992 were located organizationally in two different ministries: (1) the Institute Pédagogique Nationale (National Pedagogical Institute or IPN), the technical research branch of the Ministry of Basic Education, and (2) the Institute Supériere de Formation et de Recherche Appliquee (Higher Institute of Training and Applied Research or ISFRA), a research unit of the Ministry of Secondary and Higher Education. ${ }^{7}$ With input as well from USAID/Washington, it was also decided to orient IEQ activities to complement BEEP.

Phase I IEQ research examined factors that affect French language learning, with ISFRA researchers highlighting health, nutrition, sanitary environment, sociocultural, and other characteristics of children and IPN researchers illuminating instructional practices during reading and language arts lessons in first and second grade classrooms in eleven schools spread across four regions.

The focus on factors affecting French language learning was encouraged by an official in USAID/Mali, based in part on research conducted under the auspices of BEEP which evidenced limited French language literacy among Malian children. However, this USAID/Mali official also discouraged a focus on bilingual approaches, involving French and one of the maternal languages, prescribing that U.S.-funded projects should avoid actions that might be interpreted by the French government as interfering with French-Malian relations, particularly in the area of language policy. Because of this input and given the prevailing language-ineducation policy of the Malian government at the time, no consideration was given to studying the teaching and learning of maternal languages. This is despite the fact that there were approximately 100 schools implementing bilingual programs, and that some Malian educators' views were in line with the conclusion of an evaluation 
(conducted in the context of the USAID-funded Advancing Basic Education and Literacy [ABEL] project in the late 1980s - see Hutchinson 1990) of a national experiment in the use of maternal languages. This research concluded that the use of maternal languages as part of a convergent method of achieving bilingualism had some advantages in some situations over the French immersion approach.

With the guidance of U.S. consultants (e.g., during a seminar held in Mali in April 1993), the ISFRA and IPN researchers designed studies, developed instruments, and collected data in 11 school communities. Data were collected via observation of first and second grade classrooms and communities as well as through interviews with pupils, teachers, school directors, and parents.

Phase I research suggested that a variety of factors had an influence on students' success in learning French. These factors included students' attendance in preschools and Koranic schools, the use of French in students' homes, the distance from home to school for students, the level of education of students' parents, the availability of study areas with lighting in students' homes, communityschool relations, the children's opportunity to take books home, and the use of creative, nonofficial teaching strategies by teachers. Other factors were found not to discriminate between "good" and "poor" students and/or "performing" and "nonperforming" schools, ${ }^{8}$ although these were separated into "nondiscriminating" and "qualified nondiscriminating" factors. The latter factors, while not related to student or school performance in the IEQ Phase I research, were considered worthy of further consideration because either other research or professional insights indicated that they should be discriminating factors. These included the child's liking folk tales, ability to recite legends in her/his maternal language, physical and nutritional health, use of maternal language in the classroom, ${ }^{9}$ as well as the teacher's use of student groups, gestures, concretizing lessons, and didactic materials.

The research findings were discussed at a national Colloque (or conference), which was organized by the IEQ/Mali team (with assistance of U.S. consultants) on 26 to 29 April 1994. In attendance were the both ministers of education, including the new, recently appointed, Minister of Basic Education; 4 regional educational directors; 12 principals; 12 teachers; 12 parents; 9 basic education inspectors; and 29 representatives of donor agencies (including USAID), international organizations, and policy making bodies. At the Colloque the following intervention ideas were decided upon for piloting in Phase II:

- teacher training to facilitate the better use of teacher manuals and guides and to promote the use of didactic materials, folk tales, and small group instruction in large classes;

- improving pupil transportation between home and school;

- creating school canteens to improve pupils' health and nutrition; and 
- establishing community centers to provide supervised settings with good conditions for studying. ${ }^{10}$

Following the Colloque, the HCRT (with the guidance of U.S. consultants) organized four regional workshops (one in August and three in November 1994), at which teachers, principals, inspectors, pedagogic advisors, community development technicians, regional education directors, and parents learned about the research, were oriented to two of the above-noted interventions, and received some general training in how to implement these. It had been decided by the time of the first workshop to limit the actual interventions to only the first and fourth interventions listed above in order to make the project more manageable.

The implementation of these interventions and their effect on French language learning was initially planned as the main focus for IEQ's Phase II. However, a new Minister of Basic Education took office in January 1994 and launched an educational reform initiative, Nouvelle Ecole Fondamentale (New Fundamental School or NEF), designed to promote the teaching of maternal languages as part of a convergent method to promote bilingualism. The new Minister outlined the NEF reform at the April 1994 Colloque, and subsequently announced that all educational projects in Mali, including IEQ, would need to be cohesive with NEF. Discussions between the Minister and the IEQ Project Director, a U.S. consultant, and members of the IEQ/Mali team allowed a clarification of IEQ's focus ${ }^{11}$ and led to changes in the sample (see below); thus, the new Minister became satisfied that IEQ was compatible with NEF.

Even as this potential barrier to continued IEQ project work in Mali was being overcome, other developments created an aura of uncertainty for those involved. In addition to a teachers' strike, which resulted in the 1993 to 94 school year ending in February (versus July) these included discussions begun during 1994 in the U.S. that eventuated: (1) in the September 1995 decision to terminate IEQ "core" funding for work in Mali and (2) in the January 1996 signing of a "buy-in" contract in which USAID/Mali would fund IEQ's work in Mali.

Despite the fiscal uncertainties (but with schools in operation in the 1994 to 95 academic year), the IEQ/Mali team in January and February 1995 conducted follow-up visits - including classroom observations and interviews with teachers, principals, pupils, and parents — to 21 (8 convergent method [CM] and 13 "classical" French immersion approach schools) of the 42 "intervention" schools to monitor how the interventions were being implemented. The findings indicated that (1) very little work had been done in any region towards the establishment of the community study centers and (2) implementation of classroom instruction interventions (e.g., small group work versus whole class instruction, use of folk tales and legends, strategic use of maternal languages, ${ }^{12}$ and development and use of didactic materials) varied widely across schools and regions. 
In June 1995, the IEQ/Mali team conducted a more substantial investigation, termed the "testing stage" of IEQ's second phase. In-depth observations were undertaken in first and second grade classrooms in 12 (8 CM and 4 were "classical" approach schools) of the 42 "intervention" schools, focusing particular attention on a small sample of male and female students identified as "good" and "poor" students. Additionally, language tests (French and/or the relevant maternal language) were administered to 39 (20 "classical" and $19 \mathrm{CM}$ ) schools of the 42 in the "intervention" sample as well as 30 (22 "classical" and $8 \mathrm{CM}$ ) schools of the 42 in the "control" sample. Finally, data were collected from 71 principals, 110 teachers, as well as a sample of pupils and their parents.

Initial results indicated that teachers in intervention schools, especially, were orienting their classes to the "needs" of the children and moving from "autocratic" to more "democratic" pedagogies. Moreover, students in intervention schools were assuming greater autonomy in class and were taking greater initiative in learning, particularly in the CM schools. Parents indicated that they were happy and surprised with the degree of involvement in learning taken by their children.

During the data collection in the testing stage, conversations between researchers, teachers, school directors, parents, and students not only provided opportunities for researchers to gather information from the field, but also offered a chance for dialogue concerning findings obtained from analyzing the data gathered during the follow-up visits stage. After the data from both stages of Phase II were collected and analyzed, research reports were disseminated (by October 1996) and a post-Phase II seminar was planned to bring together decision-makers, teachers, and other education stakeholders to discuss the findings from the research and implications that might be derived for improving educational quality.

\section{Conclusion}

In this paper we have examined the political dimension to IEQ project efforts to conduct classroom-anchored research and link it to educational policy and practice. That is, we have explored how such activity was enmeshed within relations of power and resource distributions and involved people who worked and/or lived in local school communities, other citizens of the respective countries who had regional and national responsibilities, and "foreign" participants who represented bilateral and multilateral agencies.

Research activity, Pan (1990:12) suggests, is political in the process of determining "the directions and topics of research." Power relations - in addition to professional and technical issues - have to be considered in understanding the focus and design of the IEQ research in the respective host countries. To start with, recall that in all three countries it was decided to focus IEQ research on USAIDfunded reform initiatives (PREP in Ghana, BEST in Guatemala, and BEEP in 
Mali), although others were considered. While Ministry of Education officials (and other in-country personnel) in each country participated in the discussions, their was a clear pattern of influence by USAID officials - both those in Washington and those in the Mission of each core country. Additionally, with respect to Ghana, we can point to the influence of a USAID Mission official during Phase II to: (1) increase the size of and regions included in the sample; (2) concentrate on the teaching and learning of English (to the exclusion of math and science); and (3) push ahead with implementing pedagogical interventions. And during Phase III both USAID/Ghana and the U.S.-based IIR consultants weighed in to shift CRIQPEG's research focus toward the upper years of the primary school. In Guatemala, USAID officials (in conversation with Ministry officials) were in large part responsible for the decision to conduct a longitudinal evaluation study of NEU/BEST. Moreover, subsequent delineation of the research design was undertaken primarily by a U.S.based researcher and a Colombian, who was working for a U.S.-based consulting firm was overseeing the implementation of the NEU program, in addition to the HCRT Coordinator. And in Mali a USAID Mission official initially discouraged IEQ from considering even an experimental comparative focus on a convergent methodology bilingualism approach, despite an USAID-funded evaluation recommending that approach. Later, when a new Minister of Education was appointed, IEQ was forced to shift its focus to include consideration of this transitional bilingual approach combining French and maternal languages.

Research activity is political, Pan (1990:12) also suggests, in the interpretation of "the results of the research." In decision-oriented research (Cooley and Bickel 1986), such as IEQ's, the process involves more than interpreting findings but also seeking to influence policy and practice. For example, with respect to Ghana, we observed how, although Phase I research findings pointed clearly to needed policy changes (concerning the distribution of textbooks and accountability for their damage when used by students), the changes did not take place until more than one year later; indeed, the policy changes were not made until another cycle of research and dialogue had occurred. In Guatemala the "dialogue" process appeared much of the time to serve the purpose of developing the commitment and skills of the expanding population of teachers (etc.) who were to implement the NEU program. Thus, the linking of research to policy and practice had more to do with promoting and legitimating the reform initiative than it did with the refining or changing policy and practice reform proposals. And, finally, in Mali we saw how factors, which were not found by the IEQ research to affect language learning, not only made it into the research report as "qualified nondiscriminating factors," but also shaped the interventions that were eventually proposed and implemented. That these ideas were promoted because they were in line with the "professional" judgments of Malian educators as well as U.S. consultants, of course, illustrates that politics and 
knowledge/power relations are connected to professionalism (Ginsburg 1997), as well as to research.

Moving further beyond Pan's (1990) more micro-political analysis of research, we suggest that the politics of research is also apparent when we examine the institutional arrangements organized for the research teams. ${ }^{13}$ First, note that at certain times during the project (e.g., immediately after the aborted coup in Guatemala and in the final year of the project in Mali) USAID withheld IEQ core funding, and thus financial resources were not available to support the research activity of the host country research teams or the U.S. research support teams. Second, we saw in Ghana that CRIQPEG was created as a unit of the University of Cape Coast, which provided the researchers with an academic base, but with limited time and other resources to engage in IEQ research activities. Third, in Guatemala, ministerial changes - resulting from an administration replacing an appointee, an aborted coup d'état, and the election of a new president complicated and delayed plans to create an organizational home for the HCRT. The initial proposal for a unit in the Ministry of Education was changed to a unit in the Universidad de Valle, although this arrangement was not formally in place until the final year of the project. Fourth, with respect to Mali, the decision to organize the HCRT with members from two organizations (IPN and ISFRA) came about because: (1) the Ministry of Education was reorganized into two separate ministries during the course of negotiations about including Mali as a core country in the IEQ project and (2) USAID/Mali objected to the proposed involvement of a third, non-ministry-related organization of U.S.-educated, Malian researchers. Power and resource distribution issues, thus, clearly shaped the institutional arrangements within which HCRT's undertook their research activity. ${ }^{14}$

Finally, we need to consider the political dimension of IEQ research activity in that it was pursued within a context of the globalization. Here we are not only referring to the power and resource distribution issues tied to the globalization of educational reform (Ginsburg 1991). We are also suggesting that the research efforts linked to such reform rhetoric and practice should be examined within the existing power relations and distribution of resources of the global political economy more generally (Braun 1997). That IEQ was a U.S. government project, providing "aid" to less "developed" (read as less powerful and wealthy) countries should be mentioned. And, certainly, the choice of IEQ core countries can be understood as reflecting not only political relations between the U.S. government and the respective host country governments, but also global economic relations - as U.S.-based multinational corporations seek to disperse production to and increase consumption in "developing" countries, which have the "right" characteristics. Moreover, the fiscal challenges that IEQ faced in pursuing its objectives were constrained by "neo-liberal" initiatives to reduce the state's role in funding social services like education. Such initiatives not only limited the resources allocated to the education 
sector by host country governments, which were operating under World Bank or IMF "structural adjustment" programs, but contributed to the downsizing of USAID and the reductions in funding for IEQ that occurred during the course of the project.

\section{NOTES}

1 This manuscript was developed as part of the Improving Educational Quality (IEQ) project (Contract \# DPE-5836-C-00-1042-00), a five-year project centrally funded by USAID undertaken by the Institute for International Research (IIR) as the prime contractor along with Juarez and Associates, Inc. and the University of Pittsburgh as subcontractors. A second, five-year IEQ project (Contract \# HNE-I-97-0029-00) commenced in 1997 [DRAFT: 18 September 1999].

2 While all USAID missions with education portfolios were invited to participate, many did not respond to the invitation. Of those responding, these three were selected after negotiations about the goodness of the fit between the IEQ project and the on-going initiatives in the education sector in the various countries. Thus, the preferences of officials in USAID Missions and "foreign" government Ministries of Education — as well as those of the USAID contract officer and IEQ management team - shaped the selection process. However, we should note that some countries do not have USAID Mission or one with an education portfolio, thus pointing to global political economic relations as part of the explanation of which countries were included in the IEQ project.

3 While time and financial constraints meant that our documentation research did not replicate the ideal described by Clark (1988), considerable effort was expended on this activity. For example, instead of engaging in first-hand documentation of all IEQ project components, processes, and interactions, the documentation team (comprised of the authors of this article) analyzed a variety of documents and interviewed key participants in the IEQ project in each country. The following types of documents and other artifacts were examined: technical proposals; weekly, monthly, semi-annual, and annual reports prepared by IIR with input from other (U.S. and non-U.S.) members of the project team; IEQ project newsletters; trip reports prepared by U.S. consultants upon their return from one or more of the core countries; research reports, other documents, and videos of schools and classrooms produced by members of the Host Country Research Team in each core country (Ghana, Guatemala, and Mali). In addition, beginning in March 1994 and continuing until the end of the project, a series of on-going interviews were conducted with the Project Director and the majority of U.S. consultants involved in IEQ and a sample of the key members of the Host Country Research Teams from the three core countries. These interviews were conducted face-to-face, by telephone, fax, regular mail, and via e-mail. Through these mechanisms information was gathered to clarify and augment what was included in the documents, to focus informants' feedback on drafts of the respective stories, and to identify new activities or themes to explore (see also Adams et al. 2000; Ginsburg and Adams 1996).

4 After being initially framed as a longitudinal evaluation study of the NEU component of BEST, the research was shaped primarily by the Guatemalan Coordinator of the HCRT, an American researcher from Juarez and Associates, and a Colombian consultant of the U.S.-based Academy for Educational Development who was working with the Ministry of Education on the NEU component of the BEST project. Some additional input was given by other ministry personnel and from region and department level administrators (in Phase I) and region and department levels administrators, supervisors, teachers, and parents (in Phases II and III). 
5 While discussion and reflection were emphasized, the workshops functioned more like sessions to inform educators about, and to motivate educators to implement, the NEU approach than a dialogue about whether the NEU program should be continued or how it should be altered in any substantial way.

6 In 1991 a military government, which had ruled since 1968, was overthrown. A year later multiparty elections were held, with the new government being inaugurated on 8 June 1992 - the month before discussions about Mali's involvement in IEQ commenced. Within four years Mali would be described as one of Africa's “most vibrant democracies" (French 1996:A3).

7 Having the IEQ/Mali team based in two (recently reorganized) units proved complicated at times, in that representatives of the two organizations disagreed about where documents should be stored and how authorship on reports should be arranged. However, the relationship between the two units and their ministries improved over time, with many people involved in the project from Mali and from the United States viewing the IPN-ISFRA collaboration as a major accomplishment of the IEQ project.

8 The distinction between performing and nonperforming schools was made by school inspectors based on a number of criteria, including: end-of-year exam results; rates of attendance, expulsion, and repetition; level of teachers' training; quality of teacher-student engagement; quantity of didactic materials; and degree of community adhesion. Good and poor students were differentiated based on their grades in all subjects and their teacher's judgments.

9 Although IEQ personnel were discouraged by a USAID/Mali official from designing a study that compared bilingual and French immersion approaches, researchers observed and noted that teachers in schools designated as employing the French immersion approach at times used maternal languages as a means of communication (e.g., to give instructions or to offer explanations) in the classroom.

10 Note that some of these proposed interventions derive directly from the findings of the IEQ research; that is, they are implied by factors found to be "discriminating" (see discussion above). However, others are not supported by IEQ findings, but are based on other research studies and/or the professional knowledge of Malian participants' and U.S. consultants.

11 The Minister came to see IEQ's emphasis on the "strategic use of local [i.e., maternal] language" as being in line with the new Minister's commitment to the use of maternal languages, even if the approach was somewhat different than the convergent methodology (CM) bilingual approach conceived of within NEF and associated with the experiments continuing from the $1980 \mathrm{~s}$.

12 Maternal languages were used as the medium of instruction in CM schools, but only in the first grade. In the second grade in CM schools, as well as in first and second grade in "classical" schools, maternal languages were also used, but mainly for giving instructions and explanations.

13 Remember also that in both Ghana and Guatemala there were major delays in setting up a key organizational element in the strategy for linking research to policy and practice, the national advisory boards, because of power struggles in which some of the key actors were involved.

14 An analysis of the institutional arrangements for the U.S. participants in the IEQ project would also indicate that intra- and inter-institutionalpower relations and resource distributions affected their involvement in research activities.

\section{REFERENCES}

Adams, Don, Mark Ginsburg, Thomas Clayton, Martha Mantilla, Judy Sylvester and Yidan YIDAN

2000 "Linking Research to Educational Policy and Practice: What Kind of Relationships in How (De)centralized a Context?" Forthcoming in New Approaches to Studying Educational 
Policy Formation and Appropriation, edited by Bradley Levinson and Margaret Sutton.

New York: Ablex.

AgbodeK A, Francis

1992 An Economic History of Ghana From the Earliest Times. Accra: Ghana Universities Press. BODEMANN, Y.

1978 "The problem of sociological praxis." Theory and Society V: 387-420.

BокАмвА, E.G.

1991 "French Colonial Language Policies in Africa and Their Legacies." Pp. 175-213 in Language Planning: Focusschrift in Honor of Joshua A. Fishman, edited by D.F. Marshall. Amsterdam: John Benjamins Publishing.

BRAUn, Denny

1997 "The Rich Get Richer: The Rise of Income Inequality in the United States and the World." Chicago: Nelson-Hall.

ChAPMAn, D.W. and C.A. CARRIER (Eds)

1990 Improving Educational Quality. New York: Greenwood.

CLARK, T.

1988 "Documentation as Evaluation: Capturing Context, Process, Obstacles, and Success." Evaluation Practice IX (1): 21-31.

COOLEY, William and William BICKEL

1986 Decision-Oriented Educational Research. Boston: Kluwer-Nijhoff Publishing.

FoucAult, Michel

1980 Power/Knowledge. New York: Pantheon.

FRENCH, H.

1996 “In One Poor African Nation, Democracy Thrives.” New York Times (October 16): A3.

GILBERT, Rob

1997 “Issues for Citizenship in a Postmodern World.” Pp. 65-81 in Citizenship Education and the Modern State, edited by Kerry Kennedy. London: Falmer.

Gins BURG, Mark (Ed.)

1991 Understanding Educational Reform in Global Context: Economy, Ideology and the State. New York: Garland.

1995 The Politics of Educators' Work and Lives. New York: Garland.

GINSBURG, Mark

1997 "Professionalismor Politics as a Model for Educators' Engagement with/in Communities." Pp. 5-12 in Expertise versus Responsiveness in Children's Worlds: Politics in School, Home and Community Relationships, edited by Maureen McClure and Jane Lindle. 1996 Yearbook of the Politics of Education Association. Washington, D.C.: Falmer Press.

2000 "Democracy, worker-consumer-citizens, and teacher education: Theoretical musings with illustrations from research in Mexico." Democratizing Education and Educating Democratic Citizens: International and Historical Perspectives, edited by Leslie Limage. New York: Garland.

Ginsburg, Mark and Don Adams (Eds)

1996 Policy-Practice-Research-Dialogue/Dissemination Spirals in Improving Educational Quality. Pittsburgh, PA: Institute for International Studies in Education, University of Pittsburgh. 
Ginsburg, Mark and Leopold Klopfer (with Thomas Clayton, Michel Rakotomanana, Judy SYLVESTER and Kit YASIN)

1996 "Choices in Conducting Classroom-Anchored Research to Improve Educational Quality in 'Developing' Countries.” Research Papers in Education XI (3):239-54.

Gins BURG, Mark and Beverly Lindsay (Eds)

1995 The Political Dimension in Teacher Education: Comparative Perspectives on Policy Formation, Socialization, and Society. New York: Falmer.

HALLAK, J.

1990 Investing in the Future: Setting Educational Priorities in the Developing World. Paris: UNESCO/IIEP and Oxford: Pergamon.

HAYES, Katherine

1993 Effective Multigrade Schools: A Review of the Literature. Washington, D.C.: USAID. HutChinson, J.

1990 Evaluation of the Experiment in National Languages in Primary Education in the Republic of Mali. Washington, D.C.: USAID-ABEL Project.

\section{INTER-AGENCY COMMISION}

1990 World Declaration on Education for All. New York: Author.

Jones, Susan

1991 The Battle for Guatemala. San Francisco: Westview Press.

LATHER, Patti

1991 Getting Smart: Feminist Research and Methodology With/in the Postmodern. New York: Routledge.

MCTAgGert, R.

1991 “Principles for participatory action research.” Adult Education Quarterly 41(3):168-87.

OuAne, A.

1994 “Mali: System of Education.” Pp. 470-72 in International Encyclopedia of Education 2nd ed, edited by T. Husén \& T.N. Postlethwaite. London: Pergamon.

PInTo PAIZ, Ilena E.

1994 Estudio de la Realidad de Guatemala. Guatemala City: Universidad Landívar.

PAN, D.

1990 “Ivory Tower and Red Tape: Reply to Adler.” Telos 86:109-17.

POPKEWITZ, Thomas

1991 A Political Sociology of Educational Reform: Power/Knowledge in Teaching, Teacher Education and Research. New York: Teachers College Press.

Ross, K.N. \& L. MAнLCK (Eds)

1990 Planning the Quality of Education. Paris: UNESCO/IIEP and Oxford: Pergamon Press.

RoTHCHILD, Donald (Ed.)

1991 Ghana: The Political Economy of Recovery. Boulder, CO: Lynne Rienner Publishers.

STEnhouse, Lawrence

1975 Introduction to Curriculum Research and Development. London: Heinemann.

\section{UNESCO}

1991 World Education Report 1991. Paris: Author. 
WOLF, J.M.

1995 An Analysis of USAID Programs to Improve Equity in Malawi \& Ghana's Education Systems. Technical Paper No. 10 (September). Washington, D.C.: US Agency for International Development.

WORLD BANK

1988 Education in sub-Saharan Africa. Washington, D.C.: Author.

YевоAн, Vida

1992 Ghana's Policy Adjustment Initiative: Opportunity for Renewal. World Bank Paper No. 132. Washington, D.C.: The World Bank. 